\title{
Effect of Soil Fumigation Used in the Control of Pineapple Nematodes in Puerto Rico
}

\author{
Alejandro Ayala, Jessé Román, and Héctor Gandia ${ }^{1}$
}

\section{INTRODUCTION}

Pineapple ranks as the most important cash crop among the fruits of Puerto Rico. During the last 10 years its production has been increased to the point that, in the crop year of $1958-59$, its farm value was $\$ 2,020,000$. Part of this increase has been the result of the use of new insecticides, herbicides, fungicides, and perhaps most important of all, the use of nematocides.

The problems of nematodes in pineapple production and the subsequent efforts to effect their control, have received much attention during the past 50 years, particularly in Hawaii where most of the work has been performed. Larsen, in $1910(11),{ }^{2}$ recommended soil treatments such as the use of catch crops, chemicals, desiccation, and steam-sterilizing methods, and the use of resistant varieties for their control. Watson (19) recommended heavy applications of cyanamid to the soil for root-knot control in Florida. Johnson $(8,9)$ and Johnson and Godfrey $(10)$ reported the results obtained in nematode control and striking increases in plant growth and yield of pineapples in soil treated with chloropicrin. In these experiments more than 44 different chemicals were tested, but chloropicrin was superior to all of them, the only one comparable in effects to steam sterilization. In 1943 (3), a report of research in Hawaii described the nematocidal properties of dichloropropene-dichloropropane (D-D).

In $1957 \mathrm{Py}$ et al. (12), reported the use of fallow and of D-D for the control of pineapple nematodes in Guinea and recommended the use of Nemagon. Collins (6) suggested the possibility of the development of resistance in nematodes in a rotation fashion, to counteract this characteristic of the parasite. Colbran $(4,5)$ obtained good results using Nemagon, D-D, EDB, and Vapam to control nematodes in pineapple fields in Queensland, Australia.

The first step toward the control of nematodes in pineapple fields in Puerto Rico was probably undertaken by Henricksen (7) who, in 1927, mentioned the occurrence of nematodes in the Island and recommended the use of sulfur for their control. Alvarez García and López Matos (1) conducted experiments using heavy dosages of several nematocides. They

1 Assistant Nematologists and Horticulturist, respectively, of the Agricultural Experiment Station, University of Puerto Rico, Río Piedras, P.R.

2 Italic numbers in parentheses refer to Literature Cited, pp. 89-90. 
had striking increases in yields and good slip and sucker production, which led them to conclude that nematodes (especially root-knot, Meloidogyne sp.) constituted a great problem for the production of pineapples in the Island. Since then nematodes have been cited as one of the causes of decline in pineapple production of the Red Spanish variety. In 1957 the senior author (2) conducted a study of the nematode populations in pineapple fields, and concluded that a great part of the crop is lost because of nematode damage.

After studying several samples taken from different pineapple areas the need for further studies of the control of these parasites was considered of primary importance. In some instances the application of high levels of fertilizer failed to stop the decline in plantings. The same happened after applications of insecticides and other soil additives. The study of roots from those plants showed great damage, e.g. reduced root system, necrosis, galling, and several other symptoms which immediately disclosed the presence of heavy populations of plant parasitic nematodes.

In an attempt to control the noxious effects of these root parasites, an experiment using three different nematocides was conducted. In it two different methods of application were tested, e.g. split-double applications were compared with single applications of the same nematocides.

\section{MATERIALS AND METHODS}

This experiment was conducted in a Bayamón sandy clay in the Manatí region on the North Coast. In this specific locality the soil is a typical sandy knoll of very low fertility, known to produce very small pineapples, and is regarded as commercially worthless. Around these knolls on the less rolling slopes the soil has a higher clay fraction and the pineapple size and yields are normally higher. The preparation of the soil followed the regular grower's procedure, e.g. disk-plowing and disk-harrowings. After the soil was ready for fumigation, composite soil samples from each plot were taken to study the nematodes present and their populations. A balanced incomplete-block design was used in which each treatment was replicated five times. The plots were 20 by 20 feet. Treatments are given later.

EDB and D-D fumigants were applied with a tractor-drawn applicator having four injector points at 12-in centers fed by gravity, and a metering gear-pump installed for each point. The metering pumps depended on the forward travel of the machine to deliver the liquid. The broadcast system was used and points went down from 6 to 8 inches $(15$ to $20 \mathrm{~cm}$.). The treatments with methyl bromide (Mc-2) were made under plastic covers which were removed after 48 hours. Fifteen days after the first application of D-D and EDB the plots were plowed again and a second application was given. 
Two weeks before the application of the nematocides Aldrin was applied for the control of white grubs, ants, mealybugs, and mole crickets. No fungicides were applied.

Fifteen days after the second application of D-D and EDB the plots were planted to the Red Spanish variety of pineapple. Vigorous even-sized slips were selected and planted in three banks per plot, each bank consisting of two rows of plants. The banks were spaced at $62 / 3$ feet from centers with rows at 24 inches in the bank and plants at 18 inches in each row. After the plants were set, care was taken to minimize contamination of the treated plots during the usual weeding operations.

The first fertilizer application was delayed later than usual and the total amount applied later on was also smaller than that recommended. No foliar-nitrogen or iron sulfate applications were made. Heavy applications of fertilizer were made later when most of the plants were about to bloom.

The harvesting of the experiment started in May 1958, 14 months after planting, before it started to produce the second yield, when final observations were made.

Two nematode population counts were performed after treatment. The first was made 14 months after planting and included only soil samples. The last sampling was made at the end of the experiment and included soil and root samples. In all cases the samples consisted of from 6 to 8 subsamples which were then mixed in the laboratory and aliquot samples of $300 \mathrm{cc}$. processed using the screen and Barmann-funnel method. The populations were calculated to determine the nematodes found per square meter, $15 \mathrm{~cm}$. deep. Root samples consisted of $50 \mathrm{gm}$. of roots and were processed using the Waring-Blendor and Screen and Barmann-funnel methods.

\section{RESULTS AND OBSERVATIONS}

Table 1 summarizes the data obtained in relation to yield per treatment and per acre, number of fruits, and weight per treatment. As may be observed, the higher yields were obtained from the double-treated and MC-2treated plants which were significantly better than the single-treated and controls.

No significant differences were observed in using double treatments and methyl bromide. There were no significant differences among single treatments and the controls.

Table 2 shows the average weight of fruits collected monthly. Results demonstrated that most fruits were collected during July, August, and December. No significant differences were observed in time of fruiting and harvesting as related to treatment. Differences in amount and weight of fruits were more or less constant, the double treatments always being better than the single treatments and the controls. A slight deviation from 
the normal was observed in MC-2-treated plants which produced very little until July, then had a peak production in December.

Table 3 shows the nematode populations before and 14 and 28 months after fumigation, including soil and roots. Differences were not significant. The nematode populations in the fumigated plots had increased considera-

TABLE 1. Production of pineapples per acre by treatment and number of fruits, and weight per fruit, in relation to different nematocides used

\begin{tabular}{|c|c|c|c|c|c|}
\hline \multirow{2}{*}{ Treatment } & \multirow{2}{*}{ Dosage per acre } & \multicolumn{2}{|c|}{ Fruit production- } & \multirow{2}{*}{ Fruits } & \multirow{2}{*}{ Fruits } \\
\hline & & Per acre & $\underset{\text { treatment }}{\text { Per }}$ & & \\
\hline & Gallons & Tons & Pounds & Number & Pounds \\
\hline D-D, single application & 27 & 3.74 & 343.10 & 131 & 2.64 \\
\hline D-D, split double & $27+27$ & 10.13 & 931.07 & 312 & 3.20 \\
\hline EDB (W 85), single & 6 & 4.49 & 420.01 & 166 & 2.55 \\
\hline EDB, split-double & $6+6$ & 10.55 & 969.04 & 349 & 2.64 \\
\hline $\mathrm{MC}-2$ & $1 \mathrm{lb} . / 100 \mathrm{sq} . \mathrm{ft}$. & 9.28 & 852.06 & 303 & 2.79 \\
\hline Control & - & 1.37 & 126.14 & 82 & 1.54 \\
\hline
\end{tabular}

TABLE 2.-Fruit production (pounds) of pineapples per month in relation to soil treatments

\begin{tabular}{l|r|r|r|r|r|r}
\hline \multirow{2}{*}{ Treatment } & \multicolumn{5}{|c}{ Production per treatment per month in pounds per acre } \\
\cline { 2 - 7 } & June & \multicolumn{1}{|c|}{ July } & August & September & November & December \\
\hline D-D 27 gal., single & 222.15 & $3,710.22$ & $1,637.86$ & 326.72 & $1,093.36$ & $1,538.76$ \\
$\begin{array}{l}\text { D-D-54 gal., split- } \\
\text { double }\end{array}$ & 121.96 & $11,765.56$ & $3,392.24$ & 331.06 & 988.81 & $3,710.22$ \\
EDB-6 gal., single & 224.33 & $4,464.90$ & $1,646.57$ & 654.49 & 329.96 & $2,521.04$ \\
$\begin{array}{l}\text { EDB-12 gal., split- } \\
\text { double }\end{array}$ & 659.93 & $14,485.88$ & $3,280.07$ & 444.31 & 449.76 & $2,293.43$ \\
$\begin{array}{l}\text { MC-2-1 lb./100 sq. ft. } \\
\text { Control }\end{array}$ & - & $7,524.99$ & $1,975.45$ & 111.08 & $1,100.98$ & $8,612.90$ \\
\hline
\end{tabular}

bly after 14 months. After 2 years the populations of the fumigated plots were not significantly different from those of the control plots.

\section{COMMON NEMATODES FOUND}

The most common plant nematodes found in the experimental plots were: The root-knot nematode, Meloidogyne incognita; the meadow or lesion nematodes, Pratylenchus brachyurus and P. zeae; the spiral nematodes, Helicotylenchus multicinctus, $H$. nannus, $H$. erythrinae; the ring nematode Criconemoides sp.; and the reniform nematode, Rotylenchulus reniformis, and 
Pseudhalenchus sp. Less common but still numerous were Tylenchus sp., Ditylenchus sp., and others like Aphelenchus, Aphelenchoides, Seinura, and Dorylaimus.

Free-living forms of the following genera were also numerous. Rhabditis, Acrobeles, Acrobeloides, Cephalobus, Alaimus, Prismatolaimus, and Teratocephalus.

\section{SYMPTOMS AND DAMAGE OBSERVED}

The differences in growth, leaf width and length, and general appearance between split-double-treated and single-treated plants were observed after the formation of the first whorl of leaves. As plants grew older these differences became more evident with the development of marked symptoms

TALBE 3.-Nematode populations before treatment, and 14 and 28 months after treatment in relation to soil fumigation during the pineapple experiment

\begin{tabular}{|c|c|c|c|c|}
\hline \multirow{2}{*}{ Treatment } & \multicolumn{3}{|c|}{ Nematodes found per $\mathrm{m} . .^{2}$ of soil $15 \mathrm{~cm}$. deep } & \multirow{2}{*}{$\begin{array}{l}\text { Nematodes found per } 50 \\
\text { gm. of roots } 28 \text { months } \\
\text { after planting }\end{array}$} \\
\hline & $\begin{array}{c}\text { Before } \\
\text { fumigation }\end{array}$ & $\begin{array}{c}14 \text { months } \\
\text { after planting }\end{array}$ & $\begin{array}{c}28 \text { months } \\
\text { after planting }\end{array}$ & \\
\hline D-D, single (27 gal.) & 375,961 & 388,100 & 345,800 & 705 \\
\hline D-D, double (54 gal.) & 292,926 & 422,100 & 783,400 & 457 \\
\hline EDB, single (6 gal.) & 479,100 & 409,100 & 792,900 & 332 \\
\hline EDB, double (12 gal.) & 419,100 & 240,200 & 750,600 & 736 \\
\hline MC-2 (1 lb./100 sq. ft.) & 619,000 & 423,700 & 440,700 & 130 \\
\hline Control & 370,138 & 436,100 & 598,800 & 459 \\
\hline
\end{tabular}

in the untreated plots as shown in fig. 1,A and compared with healthy-looking plants in MC-2 (fig. 2,A) and double-treated plots (figs. 1,B and 2,B). The control plants were characterized by a marked chlorosis, stunting, and the development of narrow and short dead-tipped leaved (figs. 3,A,B, and $4, A, B)$ and the production of small fruits. These symptoms were observed also in the single-treated plots to a certain extent (fig. 5,A,B). The plants in double-treated and MC-2 plots were healthy-looking, well-developed, and with wide and long leaves (figs. 3,A,B and 5, A,B) producing large-sized fruits.

The roots from the controls were very scarce, knotty, broomed, and necrotic (fig. 6). Roots from single-treated plants usually showed the same symptoms. The plants from double-treated plots had well-developed long roots, showing fewer knots, brooming, and necrosis, and produced healthy large fruits. 


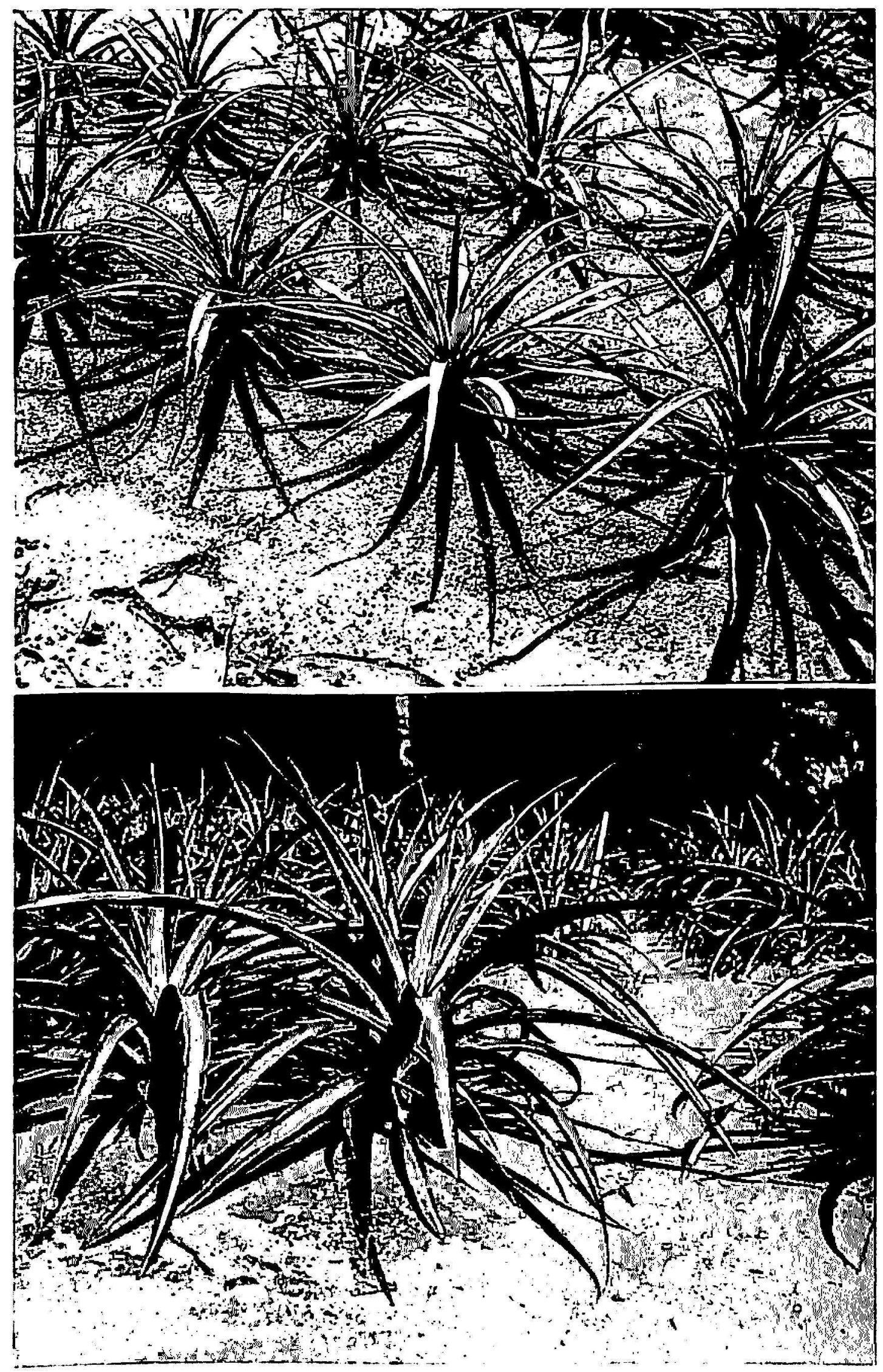

Fic. 1.-A, Stunted and chlorotic pineapple plants from one of control or nonfumigated plots. Observe lighter color and short and narrow dead-tipped leatves. This picture was taken with the same lens-opening and speed and at the same distance as pietures in B, and in fig. 2,A,B. B, Big, healthy plants of D-D double-treated plots the same age as those in $A$. 

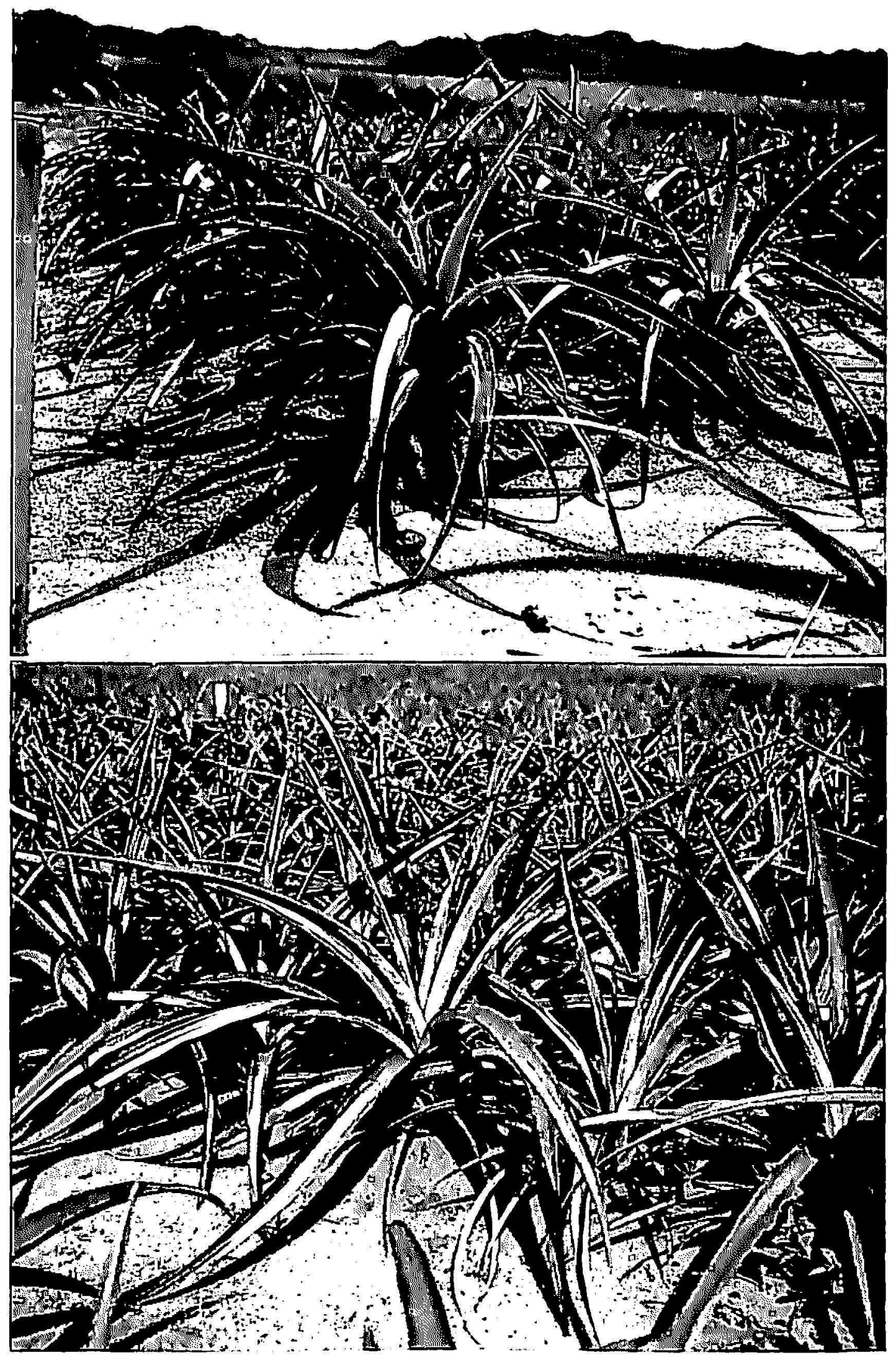

FI(i. 2.-A, Healthy pineapple plants with long and wide leaves; these are MC-2treated plants of the same age as those in fig. 1, B, Healthy-looking pineapple plants with wide and long leaves from EDB double-treated plots 8 months after planting. 

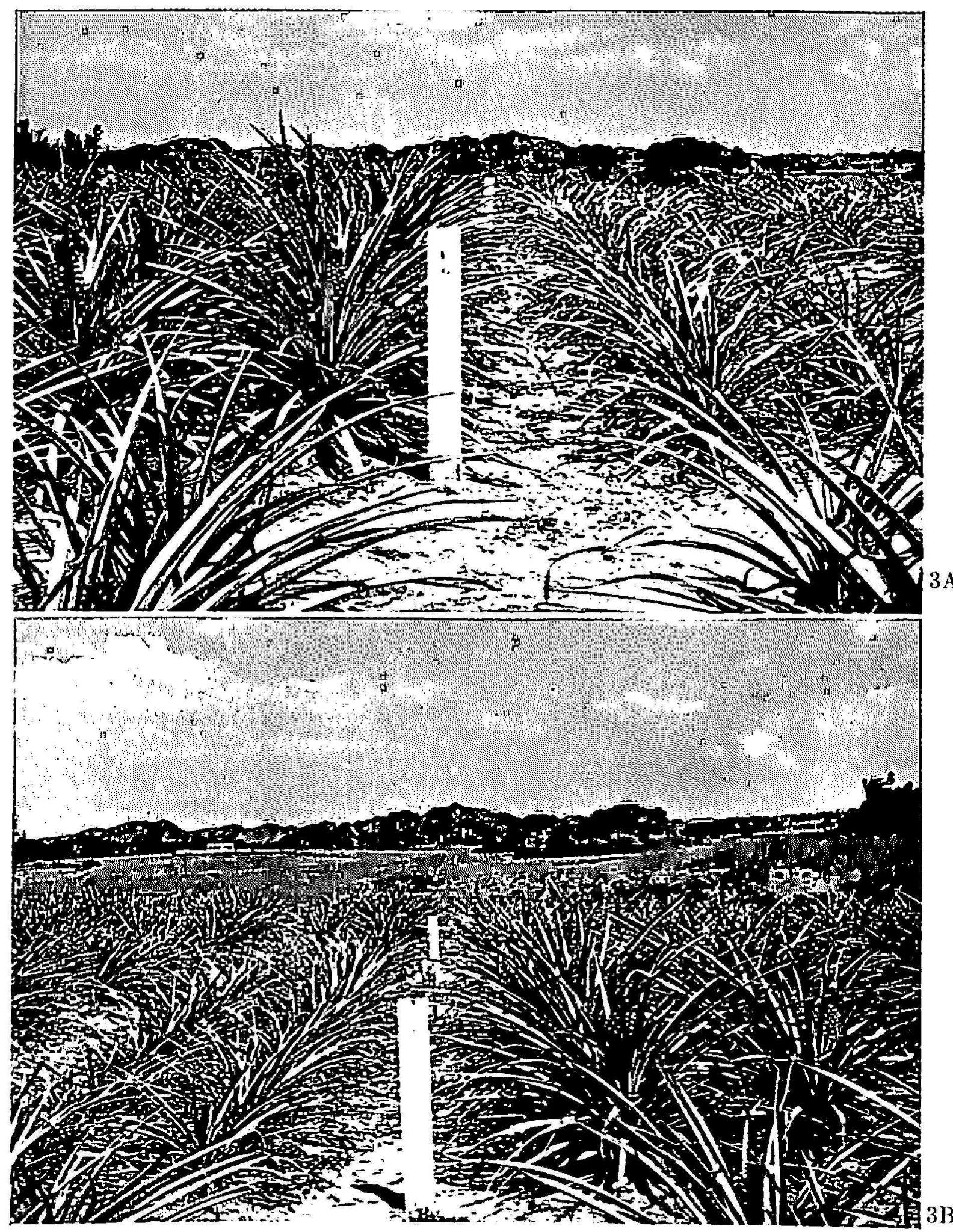

lisi. 3.- - 1, 1)ouble-treated EI)B pineapple plants at left and cont rol or nonfumigated plants at right; picture taken 23 months after fumigation. Notice bright green color of fumigated plants as compared with chlorotic, yellowish plants at the right. B, Comparison between I)-1) double-treated plot at right and untreated pineapple. plot at left. ()hserve fruits on fumigated plants and lack of them on cont rol plants. 


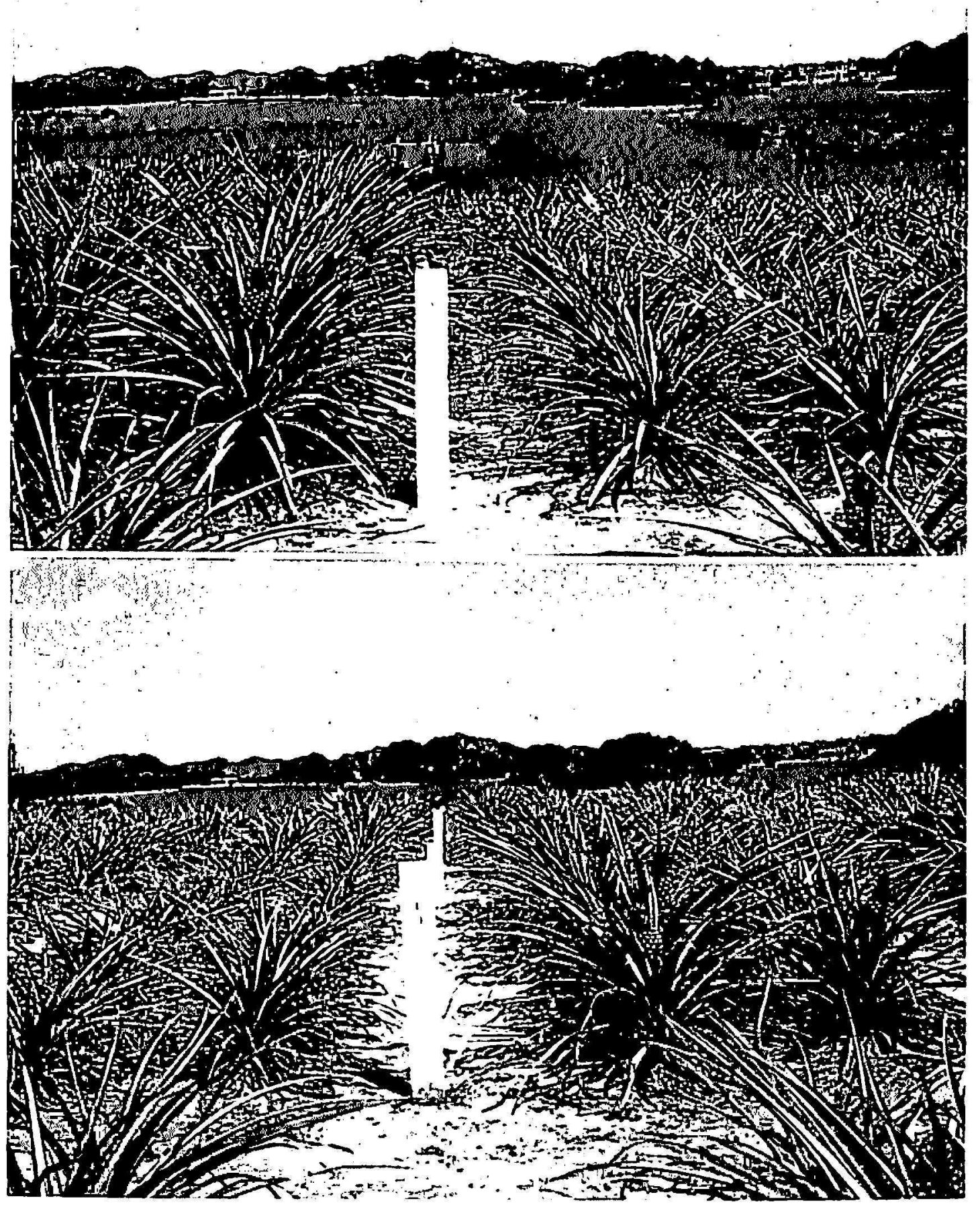

FIn, 4.-A, MIC-2-treated pineapple plot at left and nontreated plot at right. B, Pineapplo plants showing differences between nontreated plot at left and plot treated with a single application of D-D at right. 

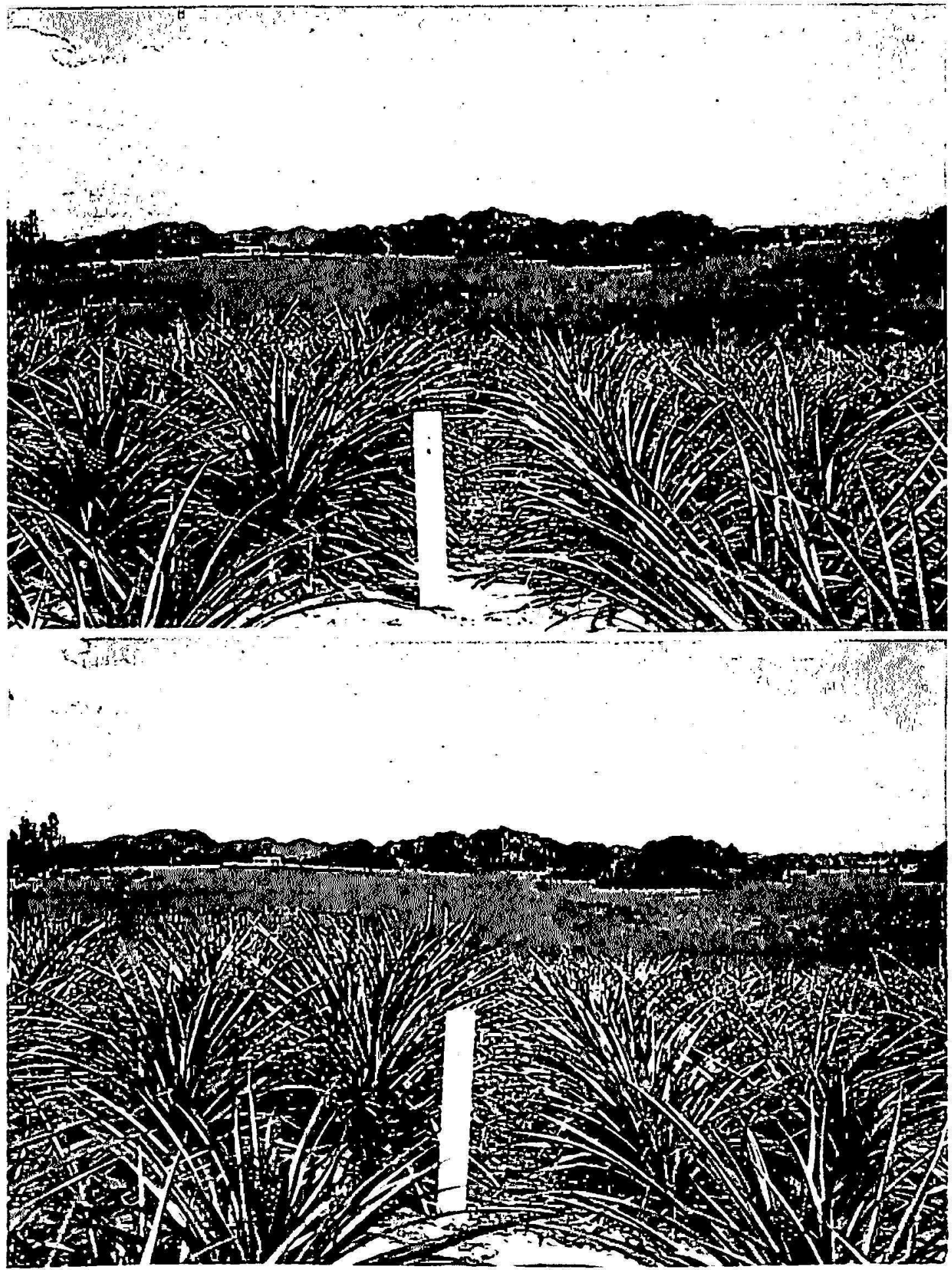

Fu(i. 5.-A, Pineapple plants 23 months after planting; EIOB double-t reat ed plot at left and single-treated plot at right. B, Pincapple plots showing the difference between D)-D double-1 reated plants at left and single-treated at right. 


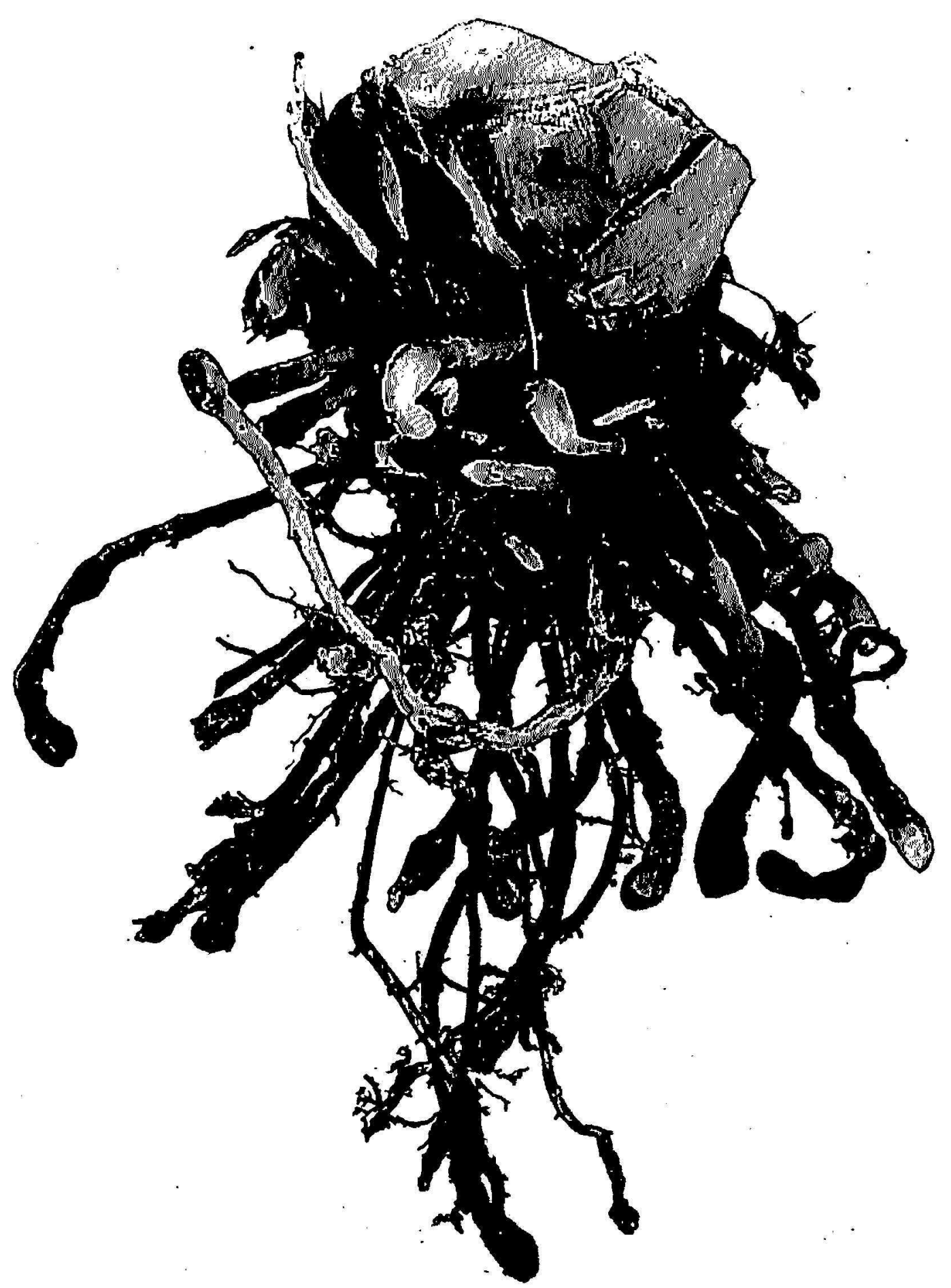

FIg. 6.-Typical root system of a control pineapple plant; observe scarce root formation and galled, cracked, and necrotic roots. 


\section{DISGUSSION AND CONCLUSIONS}

The results of the experiment corroborated the findings of earlier investigators who concluded that plant-parasitic nematodes constitute one of the most important factors in decreasing pineapple production in Puerto Rico. These investigators obtained excellent results by the application of very heavy dosages of different nematocides.

Moreover, our experiment demonstrated that these dosages can be reduced without affecting the results. Although the average yield per acre was lower, the differences between treatments and controls were greater. It should be kept in mind that the soil in which this experiment was conducted was not the best for pineapple production, and that all previous plantings had failed completely. With soil fumigation it is possible to increase pineapple yields, even in poor soils.

The method of splitting the nematocides into two applications has given very good results and seems to control the survival of large numbers of nematodes in the top few inches of soil, as occurs when single applications are made. It, of course, requires more investigation to prove that a split small dosage will produce as good results as a split heavy dosage or a single heavy dosage.

Although a good nematode kill by the fumigants was evidenced by the normal start of the pineapple plants, it was observed that many parasites still remained alive. These surviving nematodes can reproduce couickly, reaching the original numbers in a few months. The formation of a very healthy root system aids in the development of strong and healthy plants, but at the same time provides a suitable means of nematode increase. On the other hand, the plants in nonfumigated soil did not have the chance to develop good root systems because they suffered the attack of nematodes from the beginning, thus preventing their normal development of foliage and fruits.

Even when nematode populations were high in fumigated plots at harvesttime, pineapple yields were significantly better than the checks. No differences were observed in relation to time of blooming. In general, the same pattern was followed during the $\overline{5}$ months of fruit production, except in the MC-2-treated plots in which the peak in yield was reached in December, 20 months after planting. In all other treatments the peak of production was in July.

It is evident that more experimentation is needed in order to study several problems involved in the control of these pests. In fact, experiments are being conducted with the purpose of testing new nematocides, different methods of application, and other modes of control. 


\section{SUMMARY}

Pineapple production is an important source of income for Puerto Rico. The pineapple plant suffers attacks from several pests, of which plantparasitic nematodes seem to be most troublesome.

In order to evaluate and compare methods for the control of this pest several experiments were conducted in 1951, giving excellent results. More experimentation was deemed necessary to reduce the dosage of the nematocides used and to try a different method of application e.g. split dosages. An experiment was conducted in 1957 in an effort to solve this problem.

Excellent results were obtained in relation to growth and appearance of plants and to yield of fruits per acre. EDB and D-D applied in split dosages, and MC-2 were significantly better in pineapple production than single applications of the first two nematocides and the control. Production was increased at least 10 times as compared with the control.

These results are significant because they show once more that plantparasitic nematodes are one of the most important factors in determining pineapple production. When these are controlled, better yields are obtained, even in soils which are not the best for this crop. lurthermore, the dosage can be reduced with the application of the nematocides at two intervals before planting, thus increasing the efficiency of the nematocide and decreasing the cost of application.

Further experimentation is needed in order to answer several as yet unanswered questions. Experimentation continues and several tests are underway.

\section{RESUMEN}

La producción de la piña es una industria agrícola que aporta ingresos importantes para la economía de Puerto Rico. La planta de piña es susceptible a los ataques de muchas enfermedades y plagas de insectos, pero aún más lo es a las infestaciones de los nemátodos.

En el 1951 se llevaron a cabo varios experimentos para evaluar y comparar varios métodos de control de los nemátodos de la piña. Aunque los resultados de esta labor fueron prometedores, también se vió que se necesitaba ampliar la investigación en cuanto a reducir las cantidades de los nematocidas a aplicar y desarrollar un nuevo método para efectuar las aplicaciones. El método consistió en dividir las cantidades de nematocidas a aplicar, el cual se probó en un experimento que se llevó a cabo en $195 \overline{5}$. Este último experimento tuvo resultados significativos favorables con relación al desarrollo y apariencia saludable de las plantas tratadas y a la producción de fruta por cuerda.

Las aplicaciones dobles y divididas de EDB y DD, como también las de bromuro de metilo fueron favorablemente significativas en romparación 
con las aplicaciones sencillas de EDB y DD y con los tratamientos testigos. Esto es, las aplicaciones divididas de EDB, DD y de bromuro de metilo aumentaron el desarrollo y producción de la piña en las parcelas tratadas, por lo menos 10 veces más que en las parcelas sin tratar.

Las frutas de mayor tamaño se produjeron en las parcelas tratadas con DD. No hubo relación alguna entre la aplicación de los nematocidas y la época de florecida y cosecha de la fruta, ya que los resultados fueron constantes, con excepción de las parcelas fumigadas con $\mathrm{IIC}-2$, las cuales lograron sus mayores rendimientos a los 20 meses después de la siembra.

Lo significativo de este trabajo estriba en la certeza, probada experimentalmente, de que los nemátodos parasíticos interfieren con la producción normal de la piña y que si se combaten adecuadamente, la producción de esta cosecha aumenta marcadamente, aunque los terrenos no sean los mejores para su cultivo.

Este experimento también comprobó que la cantidad de nematocidas que se había estado usando puede reducirse sin menoscabar la eficacia de los mismos, lo cual redunda en una mayor economía para el usuario.

La experimentación llevada a cabo hasta la fecha evidencia el hecho de que aún quedan otros factores por estudiar con relación al uso y aplicación de los nematocidas. El programa de experimentación continúa desarrollándose en el sentido de estudiar con mayor amplitud los nuevos nematocidas y métodos de aplicarlos.

\section{LITERATURE CITED}

1. Alvarez-García, L. A., and López-Matos, L., Influence of root-knot nematodes on the decline in vigor of the Red Spanish variety of pineapple in Puerto Rico, J. Agr. Univ. P.R. 38 (1) 61-72, 1954.

2. Ayala, A., An analysis of the quantitative and qualitative composition of the nematode populations in pineapple fields in Puerto Rico, J. Agr. Univ. P.R. 45 (4) 265-99, 1961.

3. Carter, W., A promising new soil amendment and desinfect ant, Sci. 97 383-4, 1943.

4. Colbran, R. C., Nematode cont rol in pineapples, Queensland Agr. J. 86 386-8, 1960.

5. - - Chemical control of nematodes in South Queensland pineapple fields, Queensland Agr. J. 17 (3) 165-73, 1960.

6. Collins, J. L., The Pineapple: Botany, Cultivation, and Utilization, Interscience Publishers Inc., New York, N.Y. 1060.

7. Henricksen, H. C., Puerto Rico Experiment Station Report, pp. 19-24, 1927.

8. Johnson, O., The Pineapple, Paradise of the Pacific Press, Hawaii, pp. 158-221, 1935.

9. - Cont rol of chlorosis of the pineapple and other plants, Ind. \& Eng. Chem. $20724,1928$.

10. Johnson, M. O., and Godfrey, G. H., Chloropicrin for nematode control, Ind. di Eng. Chem. 24 311-3, 1932.

11. Larsen, I. O., Diseases of the Pineapple, H.S.P.A. Exp. Sta. Path. Ser. Bul. 10, 1910. 
12. Py, Tisseau, M. A., Oury, B., and Abmada, F., Ia culture de L' ananas en Guinéi, Institut Francois de Recherches Fruitieres de Outre-Mer 6, Rue du General Clergerie, Paris pp. 46-47, 1957.

13. Watson J. R., Control of root-knot by calcium cyatnamid and other means, Fla. Agr. Exp. Sta. Bul. 136 pp. 145-60, 1917. 